\title{
SCREENCAST DEVELOPMENT IN BIOLOGY ON FLIP CLASSROOM
}

\section{Ayu Ratna Puspaningsih ${ }^{1}$}

${ }^{1}$ SMA Negaeri Bali Mandara

\section{A R T I C L EI N F 0}

Article history:

Received 19 September 2018

Received in revised form 6 October 2018

Accepted 12 October 2016

Available online 20 October 2018

\section{Keywords:}

screencast video, flipped learning

\begin{abstract}
A B S T R A C T
The implementation of flipped classroom at SMA Negeri Bali Mandara (Senior high School) helped to accommodate semesteral-credit-system or SKS and to benefit from the e-learning system. However, students's achievement in Biology lesson was still 2 points below the school's passing grade (KKM) due to the inefectivity and the lack of interactivity of the learning media used. To counter this challenge therefore, video screencast was developed. This $R$ \& D project aims at: 1) to create a suitable screencast video which supporting student's learning, 2) to investigate the effecivity of the prototype, 3 ) to know the student's responses the use of screencast video to support their learning. Prototype was developed by using 4-D steps, which are: define, design, development and dissemination. The prototype was then validated by content and media experts. The product was lauched and implemented for students in Grade 12 and 10. Data response were collected by using questionnaire and finally were analysed both qualitatively and quantitatively. Students's responses were positive which supported by the fact that the use of screencast video during flipped learning improved their learning achievement.
\end{abstract}

Copyright (C) Universitas Pendidikan Ganesha. All rights reserved. 



\section{Introduction}

SMAN Bali Mandara is a boarding school established for students from disadvantaged families. The vision of SMAN Bali Mandara is to become the first school capable of producing future leaders. One of the indicators in achieving the mission is the output of students who excel in academics and nonacademics. In order to support this achievement, Bali Mandara High School applied a Semester Credit System (SKS) system in its curriculum. The SKS system makes it easy for students to regulate the amount of learning burden they want to achieve each semester, so that students can develop the academic and non-academic potential they want to develop.

In the 2017/2019 school year, the SKS system at Bali Mandara High School applied the latest SKS pattern with the implementation of the Independent Learning Activity Unit (UKBM). The use of UKBM is expected to facilitate students who are slow and fast in learning. Differences in abilities possessed by students will not affect the quality of academic output expected by using the latest SKS pattern.

On the other hand, the provincial government of Bali instructs all schools to implement e-learning. E-learning is carried out to solve problems about the limited number of classrooms and the minimum time of students in the classroom due to non-academic activities. Learners do not have to be in the classroom and in a certain time to study and do assignments, so that e-learning is very flexible to be carried out by the teacher.

To accommodate the implementation of SKS, UKBM and e-learning, then Bali Mandara High School applied flip classroom. Flip classroom is a learning process that exchanges learning activities that are usually done at school to be at home while activities to make assignments performed at home are carried out in schools (Borwn, Becki A, 2016). By using flip classroom students can learn material in the dormitory and during class learning, students can have discussions and complete assignments.

The use of flip classroom is also carried out on biology subjects for class X. Biology learning outcomes of students in class X MIPA in semester 1 of the school year 2017/2018 at 73 while the school KKM is 75. Based on these results, the average score on subjects in biology in class X MIPA value 2 points below the KKM value. This situation is caused by several factors.

First, the material characteristics of class X. The grade X material is an average memory or memorization material. Memory material is usually easily forgotten and difficult to remember, especially about known new terms. Class X material also uses many terms that are only known by students. Learning material is seen as new material learned by students, so students do not have initial knowledge about it so it is difficult to learn something new. In addition, the material studied in biology class $\mathrm{X}$ is the classification of living things which certainly requires the ability to think abstractly, because the object being studied is difficult to find around the environment.

Second, the characteristics of students. Students are still affected by the learning process while in junior high school where the teacher is the center of learning. Habits in junior high school result in students not being able to learn independently so that they always rely on the teacher as a source of information. Students also have not been able to set the time in the dormitory for independent learning due to activities outside of high academic so that in the learning process students need more time to explore and sort information.

Third, the type of media in the presentation of material given to students has not been interactive and is able to explore students' critical thinking skills. The media that is usually used is media in the form of power points, material resumes or videos related to the material. These media are also less able to facilitate students according to the learning style they have. Such media, resulting in students being less interested in learning before entering learning and also creating misconceptions. This is what causes flip classrooms to be ineffective in implementing learning.

In overcoming these problems, it is necessary to make improvements in presenting teaching materials provided to be learned from home by presenting teachers everywhere in the form of screencasts. Screencast is one of the innovations in learning that includes catches of everything on the screen, small size webcam faces, sounds and also digital pens. Jonathan Berman and Aaron Sams (2012) mention that media that is better in flip classroom is screencast. Similarly, the results of research conducted by Blair, Eric, Chris Maharaj \& Simone Primus (2015) found that students felt that just watching watching screencasts they could pass the exam. However, the screencast that has ever existed has not been interactive and has not been able to provide an overview to the teacher whether students have studied or understood the material displayed through screencast. Thus the need for screencast development in biology learning on flip classroom. The problems discussed in this study are (1) How is the development of screencast in flip classroom appropriate for biology learning ?, (2) How is the effectiveness of developing screencast in flip classroom can improve student biology learning outcomes?, and (3) How is the response students about using screencast in flip classroom on biology learning? 


\section{Methods}

This study used research and development methods with the Thiagarajan development model called the 4-D model which consisted of 4 stages, namely 1 ) the stage of defining, 2) the stage of design, 3 stages of development and 4) dissemination stage. At the definition stage, an analysis of the problems that occur, analysis of the learning process, analysis of the characteristics of students, analysis of core competencies and basic competencies and analysis of school carrying capacity so that screencasts could be determined which would be developed in a particular program. The second stage was the design stage where screencast design was carried out based on the results of the definition phase. Screencast design included determining the type of media for the material, designing the material according to the media that has been determined to determine the position of the teacher in presenting the material, and practicing screencast recording. The results of this activity were the initial screencast products.

After producing the initial screencast product, a series of assessments of the initial screencast product were conducted to test the feasibility of screencast, starting from expert validation to the initial screencast product testing for students to test the readability of the product in the learning process. For expert validation test, the instrument was used in the form of a questionnaire given to content experts (biological material), linguists and media experts. Based on the evaluation results in the form of suggestions and criticisms from experts and students, the initial screencast product was improved so as to produce the final screencast product. The final stage of this research was the deployment stage. At this stage, the final screencast product was deployed for use in biology tracking on flip classroom.

The effectiveness of screencast use was known through biology learning outcomes. Biology learning outcomes of students were obtained through applying quasi-experimental designs in the type of posttest only non equivalent control group design in the control and trial groups, each posttest result was analyzed based on the Minimum Competency Completeness (KKM), where the school KKM was 75.

The instruments used in this study were questionnaires and daily assessment tests. Validation questionnaires were given to biology learning experts, media experts and linguists while the response questionnaire using screencast was given to students to obtain data about students' responses to the use of screencast in biology learning.

Data from the results of this study were analyzed qualitatively and quantitatively. Data in the form of criticism and suggestions were analyzed qualitatively. While the feasibility test, the response of students to the use of screencast and the learning outcomes of biology students was carried out quantitatively.

\section{Findings and Discussion}

The screencast development process is carried out by the researcher through the following stages. a) Defining Phase

The research begins with analyzing the problems faced during biology learning, the learning process, the characteristics of students, the analysis of KI and KD as well as School Carrying Capacity. Based on the analysis carried out the researchers found the following: 1) The average learning outcomes of students still below the KKM, 2) Bali Mandara High School applied a credit system with the Independent Learning Activity Unit (UKBM) where students could complete the study accordingly with its capabilities, 3) Learning is carried out using a Learning Management System (LMS), e-UKBM and eassessment, 4) Non-academic activities of Bali Mandara High School students are very high, so attendance is not full, 5) Input of students has IQ of the majority is normal to the bottom, so the ability of students to learn independently with UKBM needs guidance, 6) Students come from disadvantaged families, so that the ability in the ICT field is still weak, 7) KI and KD Biology subjects in class X require material about the introduction of biology and organisms, so that it is material that requires many images, new terms and requires explanation, 8) Power supporting schools is very high especially for internet networks, ICT laboratories and ICT equipment so that technology in learning is easy to access.

Based on the analysis, the researcher developed how to deliver material effectively and knew that without meeting students, researchers could find out the extent to which students had understood the material so that biological screencast material was developed for 1 semester with the help of screencasto-matic program and presented with LMS play positively. 


\section{b) Designing Phase}

In conducting the screencast design, an analysis of the characteristics of biological material is carried out for 1 semester. Biology material for 1 semester consists of 1) biological scope, 2) biodiversity, 3) classification of living things, 4) viruses, 5) monera and 6) protists. Judging from the six materials, it is known that the material has not been studied at the previous level, has many new terms and is abstract in nature so it needs a lot of images displayed. Based on these characteristics, the good media in the process of creating screencast is power point and or video. According to Ardianti (2012) Interactive learning media is one ICT-based product that is used for media that can facilitate and arouse students' interest in learning

In accordance with Wijaya's statement, et al. (2012) multimedia is a combination of various media (file formats) in the form of text, graphics, audio, and is used to convey messages / information from the sender to the recipient of the message / information.

Power points were developed in 6 pieces according to the amount of material in semester 1 . Content of power points in general is 1) title of material, 2) KD and GPA that must be mastered by students, 3) material based on GPA demands, 4) two questions interrupted - by power point. Because biological material in semester 1 is abstract material and uses foreign terms, it is reproduced by displaying images that are relevant to the material.

Seeing the level of difficulty and practicality in using media in creating screencasts, the authors decided to use screencast-o-matic media which can be obtained for free on the internet. In addition, the use of this media can also make it easier to position the teacher's face which will explain a material without blocking the writing behind.

The results of this screencast are then video editing done first for material that displays other videos, such as in the biology scope material which is inserted a video about cardiac transponderation. Screencast that has become linked to the Playposit LMS. This LMS helps researchers to insert questions in certain minutes on the screencast so that the screencast will not continue the show before students answer the question and the researcher will get answers to what the students have answered. In addition, the advantage of using this LMS is that researchers can find out whether students have completed listening to screencasts or not and analyze students' understanding after students listen to the screencast given. Here is an example of a screencast image that has been linked to the LMS playposit.

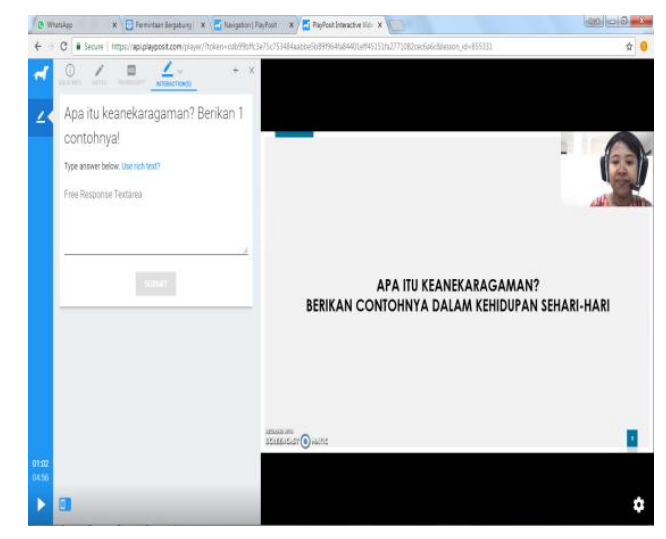

Picture 1. An example of a screencast display that is set by playposit with free questions 


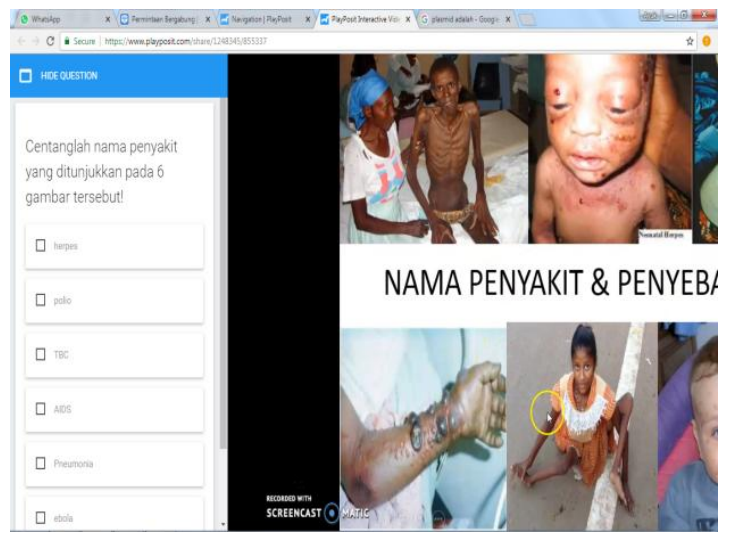

Picture 2. An example of a screencast display that is set by playposit with a choice question

c) Developing Phase

At the development stage, screencast that was designed by the researcher was carried out expert validation. The researcher used 3 expert experts namely 1) content experts, 2) linguists and 3) media experts. The three experts were given a screencast feasibility questionnaire. The following is a tabulation table of the results of the feasibility test of the 3 experts.

Table 1. Tabulation of Screencast Feasibility Test Results

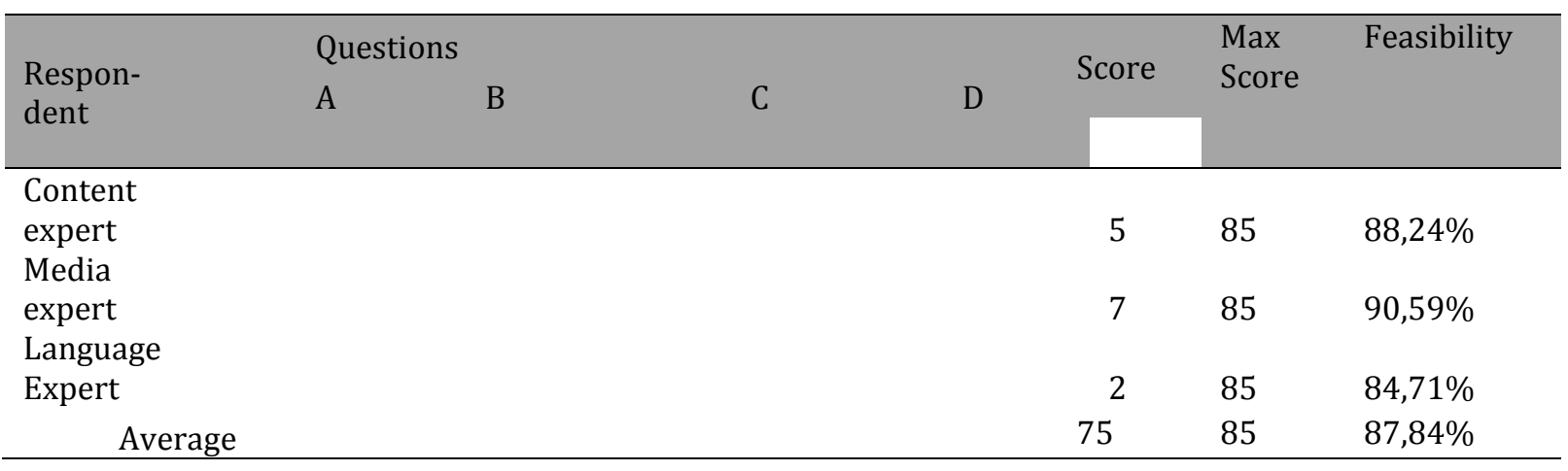

Based on the results of the feasibility test by three experts, it is known that the average Screencast feasibility score is 75, and if it is converted based on Table 3.2, it is known that the feasibility of screencast is included in the very positive category. Similarly, when viewed from each expert, the feasibility of screencast has a score above 59.5 which means that it is a good sagat category.

In addition to quantitative data from questionnaire results, also obtained qualitative data in the form of criticism and suggestions. Based on the results of content validation, there are several things that must be corrected. First, the use of the term must be corrected especially in writing terms so as not to be mixed with English. For example in the Protist writing of the word pyrophyta material. Second, new terms must be given an explanation when delivering material, as in monera material namely plasmids are circularly shaped DNA. And thirdly, it is necessary to add HOTS questions so that it is challenging between screencasts.

In terms of language validation, there are several things that must be corrected. First, the improvement of writing a few words due to typographical errors, such as the word cause becomes a cause, gondonk becomes mumps. Second, there needs to be a connecting sentence when there is a transition from a heart transplant video to an explanation of the material in the biological scope material. And third, when the explanation of transduction in monera material, where researchers use the term injection, needs to use a simpler term like the word entered.

Media validation results found several improvements. First, in the viral material there is a picture of the person who was attacked by the disease cut off when appearing on the screen so that the size must be reduced. Second, the sound in certain parts of the protist material is not so loud that it must be rerecorded.

Based on the input from these experts, the researchers made improvements, both in terms of content, language and media. This improvement produces a screencast that is more perfect than before to 
be tested on students. Improved screencast based on suggestions from experts linked back to LMS playposit then tested in class XII MIPA 2.

\section{d) Disemination Phase}

At this stage, researchers implemented the use of screencast in class X MIPA 3 of Bali Mandara High School to be assessed on student learning outcomes with the aim of knowing how far the students' effectiveness and response to the use of screencasts in biology learning on flip classroom. After this stage was passed, a product publication was carried out for all Bueleleng district MGMP teachers.

Based on the results of tabulation of student response data, the average response score of students is 44.15 . The average score of the students is included in a very positive range so that it can be concluded that the average student has a very positive response to the use of screencast in Biology learning. When viewed from individual scores, students' responses to the use of screencast in Biology learning can be described as Table 2 as follows.

Table 2. Learners Response Table Against the Use of Screencast

\begin{tabular}{llcl}
\hline No & Category & Number of Respondent & Percentage \\
\hline 1 & Very possitive & 19 & $96,3 \%$ \\
2 & Possitive & 1 & $3,7 \%$ \\
3 & Sufficient & 0 & $0 \%$ \\
4 & Less Possitive & 0 & $0 \%$ \\
5 & Not Possitive & 0 & $0 \%$ \\
\hline
\end{tabular}

Based on Table 2. it can be seen that $96.3 \%$ of students stated very positively on the use of screencast in Biology learning and 3.7\% stated positive for the use of screencast in Biology learning. The results of the interview also found that students felt very helpful in learning and understanding the material before entering class. screencast can be repeatedly listened to in certain parts so that material that is poorly understood can be repeated. If there is still material that is not understood, students can ask the teacher and other students by discussing in class so that they feel happy to be able to share. In addition, learning using screencast, making students more attractive by displaying images and videos and feeling challenged because there are questions between screencasts.

This is in line with the results of the Corner research, Nathan W. et al. (2014) who found that the provision of recorded learning was liked by students because it provided an opportunity for students to repeat the explanation on the video. Likewise, delivered by Siegle in Brown, Becky A. (2016), the explanation of the teacher being recorded can help reduce students' discomfort and confusion when the teacher explains directly in front of the class. Thus, students give a very positive response to the application of screencast in biology learning.

From the results of the trial, the XIPA 3 class X also obtained Biology learning outcomes data. This data was compared with Biology learning outcomes of class X MIPA 2 as a control class that was not treated with Screencast. The following is the data from the comparison of the completeness of the daily assessment value I in each class shown in Table 3.

Table 3. Comparison of the completeness between experiment and control group

\begin{tabular}{lllccccc}
\hline No & Class & $\begin{array}{l}\text { Number } \\
\text { of } \\
\text { students }\end{array}$ & $\begin{array}{l}\text { Students with } \\
\text { score } \geq 75\end{array}$ & $\begin{array}{l}\text { Students } \\
\text { score }<75\end{array}$ & with & $\begin{array}{l}\text { Learning } \\
\text { Completeness } \\
\text { Percentage }\end{array}$ & Criteria \\
\hline 1 & $\begin{array}{l}\text { X MIPA } \\
\text { (experiment }\end{array}$ & 7 & 2 & 23 & 4 & $85.19 \%$ & Very good \\
class) & & & & & & \\
X MIPA & 2 & & 2 & 20 & 6 & $76,92 \%$ & Good \\
(control & 6 & & & & & \\
class) & & & & & & & \\
\hline
\end{tabular}


Based on Table 3. it can be seen that in the class given treatment using screencast obtained the percentage of completeness of $85.19 \%$ which is in the category is very good, while in the control class the percentage of completeness is $76.92 \%$ which is in the good category. Thus there is a difference in the percentage of learning completeness in students who are treated with those who do not.

When students listen to the screencast through playposit, the researcher will get a picture of 1) whether the students have listened or not screencast, 2) how long the students listen to the screencast given, 3) know how deeply the students understand the material delivered through the screencast through answering questions on the sidelines of a screencast. This description can be obtained from the following data.

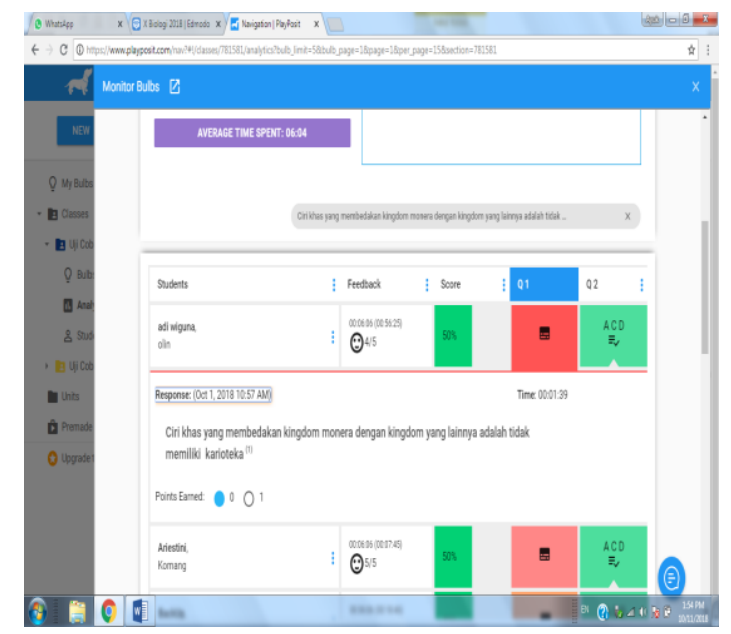

Picture 3. The score description answers the questions and completeness in listening to the screencast

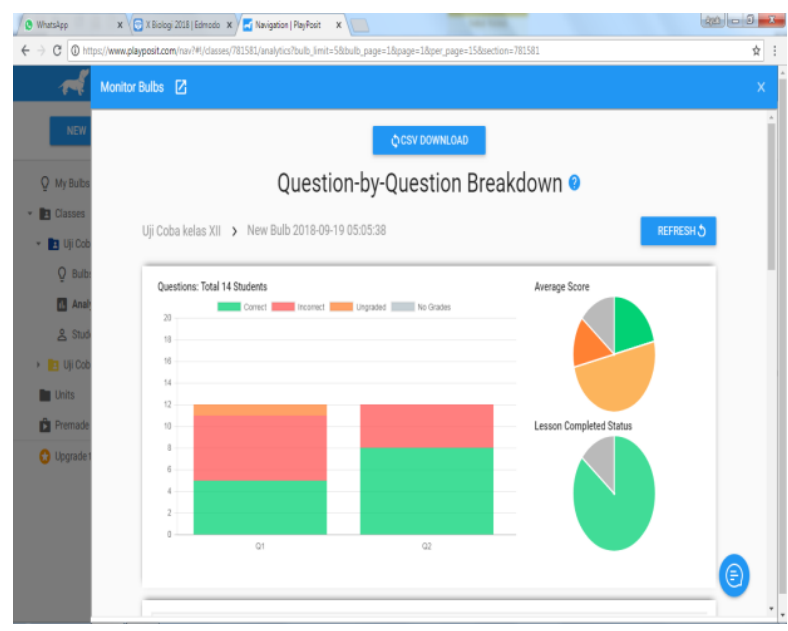

Picture 4. Scores of answers to questions in each question and duration in listening to screencasts for all students 


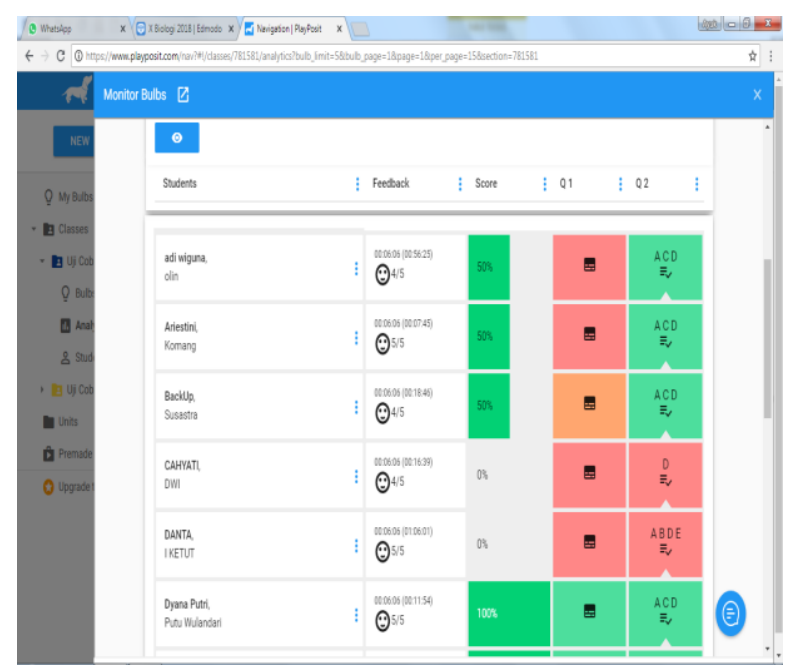

Picture 5. Overview of question answers for certain students

Based on this description, the researcher can find out the extent to which students' prior knowledge before learning in the classroom, know material that is misconceptions or poorly understood and certainly can determine the steps of learning in the classroom. Viewed from the side of students, using screencast students can 1) know the extent to which he mastered the material, and 2) can set the time in studying the material through screencast both on duration and repetition. This is what causes the percentage of mastery learning biology in the MIPA 3 treatment class is higher $(85.19 \%)$ compared to the control class, namely class X MIPA $2(76.92 \%)$. This is in line with the results of research conducted by Kholifah, Siti and Iwan Kurniawan (2016) who found that learning using screencast-o-matic software was better than conventional learning in business strategy material because students could explore the material before entering the class. The habit of studying the material before entering the class according to the results of the research by Pratiwi, Astri, Rahmat Saputra and Lukman Hadi (2017) can increase the self confidence of peseta students. Learners can be more focused, more concentration on learning can stop and replay videos in comfortable conditions and atmosphere.

In this screencast development there are two obstacles faced by researchers. First, equipment constraints. The researcher must have a good recording tool, especially in recording sound so that only the voice of the explanation person enters the recording process. This can be overcome by using a special microphone that is directly connected to the computer. Second, the preparation of the scenario. The preparation of the scenario before recording needs to get special attention, especially the selection of words during explanation. The choice of words must be in accordance with the level of development of students and students' initial knowledge. So that in writing the scenario there needs to be collaboration between one MGMP teacher and Indonesian language teacher .

\section{Conclusion}

Based on the results of research conducted, it can be concluded that (1) the development of screencast in a decent classroom classroom on biology learning is done through the stages of defining, designing, developing and disseminating, (2) The results of developing screencast in a classroom classroom that is feasible in biology learning are effective in improving student biology learning outcomes and (3) the average response of students about using screencast in flip classroom on biology learning is very positive.

Given the effectiveness and positive response to the use of screencast in flip classroom, there are two suggestions, namely 1) screencast needs to be developed on abstract and high difficulty material and 2) For schools that have not applied SKS can also use screencast in learning by considering readiness of facilities infrastructure, especially the internet and computer networks and of course pay attention to the ICT capabilities of students. 


\section{References}

Ardianti, Ni Made Yunia. 2012. Pengembangan Media Pembelajaran Interaktif Berbasis Team Assisted Individualization Untuk Mata Pelajaran Teknologi Informasi Dan Komunikasi (Tik) Dengan Pokok Bahasan Desain Grafis Pada Siswa Kelas XII SMAN 1 Sukasada. 1 (3): 219-243.

Berman, Jonathan \& Aaron Sams. 2012. Flip Your Classroom Reach Every Students in Every Class Every Day. US: ISTE.

Blair, Eric, Chris Maharaj \& Simone Primus. 2015. Performance and perception in the flipped classroom. Springer Science+Business Media New York.

Brown, Becki A. 2016. Understanding the Flipped Classroom: Types,Uses and Reactions to a Modern and Evolving Pedagogy. St. Cloud State University. Culminating project in teacher development. 52016.

Corner, Nathan W. dkk. 2014. Examining Student Perceptions of Flipping an Agricultural Teaching Methods Course. Journal of Agricultural Education, 55(5), 65-77.

Kholifah, Siti dan Iwan Kurniawan. 2016. Pengembangan media video pembelajaran berbantuan software Swishmax dan screencast o-matic dengan model flipped classroom pada Mata kuliah manajemen strategik. Jurnal Nusamba Vol 1 no 2.

Pratiwi, Astri, Rahmat Saputra dan Lukman Hadi. 2017. Pengaruh Model Flipped Classroom Terhadap Self-Confidence Dan Hasil Belajar Peserta didik Sman 8 Pontianak. Diakses arihttps://media.neliti.com/media/publications/211757-none.pdf

Wijaya, Yoga Permana. Prasaoran. Rohendi, Dedi. 2012. Efektivitas Pembelajaran Multimedia Interaktif Berbasis Konteks Terhadap Hasil Belajar Siswa Pada Mata Pelajaran TIK. (Online), (https:// yogapermanawijaya.files.efektivitas-pembelajaran-multimedia-interaktif-berbasis-konteksterhadap-hasil-belajar-siswa-pada-mata-pelajar.pd0,d.bmk), diakses 24 Juni 2013. 